\title{
THE ROLE OF PROJECT AND PROBLEM LEARNING IN DEVELOPING THE RESEARCH COMPETENCE OF STUDENTS
}

\author{
Nataliia Lyubchak \\ Postgraduate Student at the Department of Pedagogy, Administration and Social Work, \\ State Higher Educational Institution "University of Educational Management”, Ukraine \\ e-mail: natus08@i.ua, orcid.org/0000-0003-1524-0747
}

\section{Summary}

Research competence is the basis for the development of other more specific and subject-oriented competencies, since it helps the student to learn, allows him to become more flexible, competitive professional, helps to be more successful in the future, and determines the meaningfulness of life`s forming.

The article examines and analyzes the role of pedagogical teaching technologies in the development of students' research competence. The conditions for the development of research competence of students by means of modern pedagogical technologies are described. The main approaches to defining the essence and content of learning technologies are analyzed.

After the analysis of own experience, organization and conduct of educational and research activities of students, the author concludes that the use of modern educational technologies allows the obtainment of successful results in the constructing of components of the research competence of students at the Ukrainian language and literature lessons. The developmental technologies - problem and project learning are in demand the most, where the integration of theoretical and practical components, the development of creative and critical thinking, and of readiness for self-development and self-improvement are carried out.

Keywords: competence, research competence, learning technologies, problem-based learning, project-based method, project learning.

\section{DOI: https://doi.org/10.23856/3861}

\section{Introduction}

From the beginning of the XXI century, it becomes more and more obvious that the skills and abilities of scientific research are necessary not only for those whose life is already connected or will be connected to the scientific work, but they are necessary for every person. A human being is by nature a researcher; but today the research inclinations given to him from birth are not enough, so people must learn research activity. This actualizes the problem of research skills shaping in the younger generation, mastery of research, without which the forming of research competence is impossible.

Research competence is the basis for the development of other more specific and subject-oriented competencies, since it helps students to learn, allows them to become more flexible, competitive, to become more successful in the future. All of that determines the importance of research competence forming.

We believe that in terms of development of the student's personality, research competence most fully reflects modern requirements of the quality of higher education.

Each person is naturally gifted with a tendency to cognize and to explore the world around them. Properly delivered training should improve this inclination; contribute to the development of desire, which is, as usual, not enough to solve research problems. The effectiveness of 
research activity depends both on the degree of enthusiastic attitude towards this activity, and on the ability to perform it. By instilling in students hunger for research, we equip them with methods of scientific research (A. Khutorskoy, 2003).

A number of innovative teaching technologies, corresponding forms, methods and means have been developed in pedagogy in recent years. All of that have great potential in the development of the research culture of students.

It seems to us that the general requirements for the selection of appropriate learning technologies are: active and developmental character, personalized and socio-professional orientation. In a holistic educational process, learning technologies should be combined harmoniously. At the same time, while remaining in the field of the competence-based approach, the emphasis should be on technologies that ensure the forming of research competencies through the assimilation of the content of professional activities by the future specialist, as well as the development of systemic and flexible thinking, social mobility and adaptability, the ability to work in a team, the ability to take on the responsibility, readiness for continuous self-improvement, overcoming obstacles, etc.

The purpose of this article is to review and analyze the role of teaching technologies in the forming of research competence.

Analysis of scientific literature on pedagogical technologies (O. Babenko, N. Bibik, L. Burchak, L. Vashchenko, I. Drach, I. Zyazyun, O. Semenog, O. Savchenko, M. Makhmutov, G. Verbitsky, G. Selevko, A. Khutorskoy, and others) allowed us to find out that the technologies of problem-based and project-based learning are the most adequate for the task of expending the research competencies among students of a higher professional school.

In this regard, we will look deeper into the main content of these learning technologies.

\section{Problem-based learning}

Problem-based learning is also an effective way of forming and developing creative potential, cognitive activity and research skills among students.

The technology of problem-based learning is understood as "a system of specific techniques and methods that promote both the independent acquisition of knowledge and their independent use in solving new cognitive and practical problems. Problem-based learning combines the systematic search activity of students with their assimilation of ready-made conclusions of science, and the system of teaching methods is built taking into account the principles of goal-setting and problem-solving" (M. Makhmutov, 1993: 127).

For this type of education is characterized by knowledge and methods of activity that are not given in a finalized form, but are to a greater extent the subject of the search of the students themselves. The teacher reveals the possible general directions of such a search and notifies about the false paths; but the students themselves try to solve the problem with the help of the teacher's heuristic hints. The process of problem-based learning becomes similar to scientific research. This learning model goes back to the methods of D. Dewey's system - learning by doing. In the $60 \mathrm{~s}$, its version was developed by J. Bruner. The idea and principles of problem-based learning is associated with the names of such outstanding didacticists as I. Lerner, M. Skatkin, M. Makhmutov, I. Ilnitskaya, V. Okon. Research in this area is now being carried out by other representatives of pedagogical science.

By problem-based learning V. Okon understands "a set of actions such as organizing problem situations, formulating problems, providing students with the necessary assistance in solving problems, checking these solutions and, finally, guiding the process of systematizing and consolidating the acquired knowledge" (V. Okon, 1968: 184). 
In the theory of problem-based learning, reproductive and research methods are successively interconnected, including traditional methods of teaching and learning. Since in the process of problem-based learning, skills of independent, creative activity are effectively formed, and not only the scientific level of teaching is increasing, but also its motivational, emotional saturation; so, this type of teaching in a modern school plays the main role in improving the quality of training a specialist that meets the requirements of the XXI century.

This type of training presupposes the consistent and purposeful advancement of cognitive tasks given to the students, while solving those, guided by a teacher, they not only actively assimilate new knowledge, but also, they develop motivational, emotional, subject-practical and other aspects of individuality. Starting with a problem situation, the process of thinking proceeds as a search for the unknown and ends with the discovery of it and the forming of new mental paths.

Let us review the pedagogical possibilities of problem-based learning in the forming of research competencies of students. Obviously, in this case, one should consider several aspects. Firstly, by remembering which research competencies are possible to form via problem-based learning. Secondly, it is necessary to take into account the first point, by analyzing the possibilities of means of implementing problem-based learning in their forming (for example, creating a problem situation, stating a hypothesis, the proof of it, problem-based forms and teaching methods, etc.).

The first question, what kinds of research competencies can be predominantly formed in the context of problem-based learning? Problem-based learning, due to its essential features, can contribute to the forming of such core competencies as "the ability to solve problems in the field of professional and social activity independently and effectively", "the ability to act independently in conditions of uncertainty", "the ability of critical thinking", and "the desire of creative self-actualization". These possibilities of problem-based learning in the scientific and pedagogical literature have already found justification to one degree or another (M. Makhmutov, I. Lerner, D. Vilkeev, V. Andreev, etc.). However, if to consider students of the higher professional school, no special research has been carried out on this issue; so, it seems important and objectively necessary to study it. In addition, it should be emphasized that so far problem-based learning has been viewed by researchers mainly from a purely didactic standpoint. Meanwhile, in modern conditions it is necessary to look upon this concept more broadly, as upon a general pedagogical theory that allows solving not only purely didactic tasks, but also the tasks of personality development and of the forming of universal abilities in students.

\section{Project learning}

Active teaching methods are important means of developing research skills and abilities, and the project method takes one of the leading places.

The project method as a way of teaching future teachers is attractive because it is a kind of developmental education. It generates the prerequisites for the desire of students to show their creativity in educational and innovative activity; enhances stimulus for cognitive actions, develops their thinking, self-sufficiency, reliability, the ability to design, draw conclusions, and define the value of obtained results.

The personality-oriented interaction of a teacher and students is significant in such settings, when any student, according to his skills, calling, general knowledge and personal experience, has a chance to apply his erudition, universal learning steps, and creative original idea. 
The technology of project learning has great opportunities in the development of the personality of students, including research competencies.

The ideas of project learning are reflected in the studies and publications of American educators: J. Dewey, W. Kilpatrick, E. Collings who worked at the beginning of the XX century.

The theoretical basis of project-based activities is also revealed in the works of modern Russian researchers: V. Guzeev, T. Levin, N. Matyash, G. Selevko, E. Polat, I. Chechel, I. Shendrik.

Theoretical and conceptual framework of project learning technology in Ukrainian pedagogy are investigated by: N. Borisova, O. Kovalenko, O. Pekhota, G. Romanova, S. Sysoeva, K. Bakhanova, I. Ermakova, O. Pometun and others.

The research of recent years by A. Kobernik, I. Konovalchuk, T. Podobedova, which reflect the essence of the process of project-based activity, the corresponding technology and the conditions for its implementation in the educational process are of particular interest. Problems of organizing project learning activities became the subject of dissertation research by S. Izbash "Project-based activity as a factor of social and professional adaptation of students of a pedagogical university", M. Pelageichenko "Preparing future vocational education teachers for organizing project-based activities of students of secondary school", A. Zosimenko "Organization of project learning activity for future teachers in the process of studying pedagogical disciplines" and others.

Projectteaching is practiced more and more in their work by teachers, such as L. Varzatskaya and L. Kratasyuk, G. Tokman, A. Onoprienko, P. Kendzer and A. Voitenko, L. Golovko, I. Zozyuk, N. Podranetskaya.

L. Varzatskaya and L. Kratasyuk developed practical and methodological recommendations for organizing the project learning activity for students during the Ukrainian language lessons. G. Tokman sees project learning as a modern educational technology that can be used for teaching Ukrainian literature. Detailed methodical recommendations for the implementation of the project method in the educational process of secondary schools were developed by A. Onoprienko, P. Kendzer and A. Voitenko. S. Korshok and G. Boyko insist that in the process of composing new textbooks on Ukrainian literature, it is necessary to take into account the possibility of using the project method by teachers-philologists. The pedagogical technology "projectmethod" in their activity is successfully used in Ukraine by: L. Golovko, I. Zozyuk, N. Podranetskaya in the process of learning the Ukrainian language; L. Gerus, A. Demyanenko in the process of teaching Ukrainian literature.

As we can see, the study of scientific and pedagogical literature shows that a considerable number of studies have already been devoted to the development of projectlearning.

According to N. Chernilova, project-based training is marked as developmental, based "on the sequential implementation of complex educational projects, educational activity, which includes informational breaks for mastering basic theoretical knowledge" (N. Chernilova, 1997: 118).

E. Polat underlines a distinctive feature of the project method such as "... a pragmatic focus on the result that can be obtained by solving one or another practically or theoretically significant problem. This result has to be seen by the students, comprehended and applied by them in real practice" (E. Polat, 1999: 208).

Here is the definition of the project method according to A. Kobernik: "This is a learning system where students acquire knowledge in the process of planning and performing tasks that are gradually becoming more complex" (A. Kobernik, 2007: 42).

O. Pekhota writes, "at the essence of the project-based technology is the stimulation of the student's interest for certain problems what imply the possession of a certain amount of 
knowledge, and showing the practical application of the acquired knowledge, via projectactivity, namely, by finding a solution for one or a number of problems; from theory to practice" (O. Pekhota, 2001: 238).

According to the definition given in The Ukrainian Pedagogical Dictionary, the project method is an organization of educational activity, "in which students acquire knowledge and skills in the process of planning and performing practical projects-assignments" (G. Goncharenko, 1977: 205).

Defined by S. Sysoeva, the project method is one of the pedagogical technologies "which reflects the implementation of a personality-oriented approach in education (namely, pedagogical technology, although the title of the technology uses the word "method") and contributes to the forming of the ability of a person to adapt to the rapidly changing living conditions in the post-industrial society" (S. Sysoeva, 2005: 26).

The opinion of these famous teachers on the technological effectiveness of the project method is shared by I. Ermakov (Ermakov, 2005), G. Stolyarenko, A. Demyanenko (G. Stolyarenko, 2005), G. Isaeva (G. Isaeva, 2005), I. Zozyuk (I. Zozyuk, 2005), I. Gus, I. Kalmykova (I. Gus, 2005).

According to scientists, the goal of the project learning is to create conditions in which students:

- acquire the missing knowledge from various sources independently;

- use the acquired knowledge to solve cognitive and practical problems;

- acquire communication skills by working in various groups;

- develop research skills (identifying a problem, collecting information, observing, conducting experiments, analyzing, formulating hypotheses, summarizing);

- develop systematical thinking.

The project method is always focused on the independent activity of students, whether individually, in pairs, or in a group, when students work during a certain period of time. This approach is organically combined with a cooperative learning approach. The project method always presupposes the solution to some problem, which envisages, on the one hand, the usage of various methods, teaching tools, and on the other hand, the integration of knowledge and skills from various fields of science, industry, technology, and creative fields. The results of the completed projects should be "tangible", i.e., in case of a theoretical problem, there should be the specific solution found; if there was a practical problem, then the particular result ready for implementation must be presented.

The ability to use the project method is an indicator of the teachers ' high qualifications, their progressive methodology of teaching and development. It is not without reason that this technology is referred to the technologies of the XXI century that primarily develop the ability of a person to adapt to the rapidly changing living conditions in the post-industrial society.

Classification of educational projects (by E. Collings). The developer of the project method, American professor E. Collings, proposed the world's first classification of educational projects (E. Collings, 1927).

Game projects: various games, folk dances, drama performances, etc. The goal of it is the participation of children in group activities.

Excursion projects: expedient study of problems related to the environment and social life.

Narrative projects: their purpose is to enjoy the story in the most diverse forms: oral, written, vocal (song) or musical (playing the piano).

Constructive projects: the creation of a specific, practical product: making a rabbit trap, building a stage for a school theater, etc. 
Requirements for using the project method. Basic requirements for using the project method:

- the presence of a problem or task that is significant in the explorative and creative sense, requiring integrated knowledge, scientific search for its solution;

- the practical, theoretical, cognitive significance of the expected results; an independent (whether individually, in pairs, or in a group) activity of students;

- the structuring of the project content (with the indication of the results of each phase);

- the implementation of research methods: definition of the problem, the research tasks arising from it, formulating a hypothesis of their solution, discussion of research methods, recording of final results, analysis of the obtained data, summarization, correction, conclusions (implementing the brainstorming method in the course of joint research, "round table", statistical methods, creative reports, etc.

There are several approaches to the classification of projects (E. Polat, 1999: 205). E. Polat identifies five groups of projects for the dominant student activity:

- applied project;

- research project;

- informational project;

- creative project;

- role-playing project.

Projects also differentiated by their:

- complexity: mono-projects and interdisciplinary;

- duration: mini-projects, short-term, long-term;

- number of participants: individual or in a group.

The gist of project learning is that the student, in the process of working on a subject, comprehends real processes, objects, etc. It assumes that the student experiences specific situations which introduce him to deep penetration into phenomena, its processes and the constructing of new objects. Project-based education teaches and develops a project attitude towards the world, one's own life. It allows future specialists to combine educational, research and quasi-professional activities. It envisages the use of a combination of research, scientific, problem-solving and interrelated methods, as well as the integration of reflexive, presentational, research and other techniques.

Project-based learning must be considered as the main type of cognitive and research activity for university students.

\section{Conclusions and suggestions}

The technologies reviewed in the article are referred to as to the technologies of the XXI century, which provide, first of all, the ability of a person to adapt to the rapidly changing living conditions in a post-industrial society.

Based on the analysis of our own experience, organization and conduct of educational and research activity of students, we can conclude: the use of modern educational technologies allows us to achieve successful results in the forming of the components of research competence in students during the Ukrainian language and literature lessons.

Students can independently formulate goals; plan research activities alone or with others; apply the knowledge obtained from various sources outside the scope of the syllabus; are able to independently state a hypothesis; plan an experiment themselves. They can also evaluate the results of work and develop a computer presentation independently; as well as carry out reflection while presenting their work. 
Thereby, we conclude that the technologies for the forming of research competencies are diverse. However, the technology of project learning can contribute to the holistic forming of students' experience of activity in its various types (cognitive, communicative, transformative, etc.).

\section{References}

Honcharenko, S. (1997). Ukrainskyi pedahohichnyi slovnyk [Ukrainian pedagogical dictionary]. Kyiv: Lybid. [in Ukrainian]

Hetta, V. H., Hurevych, R. S. Kobernyk, O. M., Tereshchuk, A. I., \& Tereshchuk, H. V. (2008). Innovatsiini pedahohichni tekhnolohii u trudovomu navchanni [Innovative pedagogical technologies in labor training]. Uman: SPD Zhovtyi. [in Ukrainian]

Hus, I. M., \& Kalmykova, I. V. (2005). Metod proektiv [Project method]. Upravlinnia shkoloiu, 5, 8-11. [in Ukrainian]

Iermakov, I. (2005). Proektnyi pidkhid u shkoli zhyttievoi kompetentnosti [Project approach in the school of life competence]. Pidruchnyk dlia dyrektora, 9-10, 32-49. [in Ukrainian]

Zoziuk, I. (2005). Tvorchi proekty: obgruntuvannia neobkhidnosti [Creative projects: justification of necessity]. Ukrainska mova ta literatura, 45, 6-7. [in Ukrainian]

Isaieva, H. (2005). Metod proektiv - efektyvna tekhnolohiia navchannia [Project method effective learning technology]. Pidruchnyk dlia dyrektora, 9-10, 4-10. [in Ukrainian]

Mahmutov, M. I., Ibragimov, G. I., \& Choshanov, M. A. (1993). Pedagogicheskie tehnologii razvitiya myshleniya uchashihsya [Pedagogical technologies for the development of students' thinking]. Kazan: TGZhI. [in Russian]

Okon, V. (1968). Osnovy problemnogo obucheniya [Fundamentals of problem learning]. Moscow: Prosveshenie. [in Russian]

Pekhota, O. M. (2001). Osvitni tekhnolohii [Educational technologies]. Kyiv: “A.S.K.”. [in Ukrainian]

Polat, E. S. (1999). Novye pedagogicheskie i informacionnye tehnologii [New pedagogical and information technologies]. Moscow: Izdatelskij centr "Akademiya". [in Russian]

Sysoieva, S. (2005). Osobystisno zoriientovani tekhnolohii: metod proektiv [Personally oriented technologies: project method]. Pidruchnyk dlia dyrektora, 9-10, 25-31. [in Ukrainian]

Stoliarenko, H., \& Demianenko, O. (2005). Chy mozhna zastosovuvaty proektni tekhnolohii na urokakh literatury? [Can project technology be used in literature lessons?]. Ukrainska mova $i$ literature, 45, 3-5. [in Ukrainian]

Hutorskoj, A. V. (2003). Klyuchevye kompetencii kak komponent lichnostno-orientirovannoj paradigmy obrazovaniya [Key competencies as component of the personality-oriented paradigm of education]. Narodnoe obrazovanie, 2, 55-61. [in Russian]

Collings, E. (1923). An experiment with the project curriculum. New York: Macmillan. [in English] 